\title{
Status and nutritional therapy in elective and emergency neurosurgery patients
}

\author{
Estado e terapia nutricional em pacientes de neurocirurgia eletiva e urgência \\ Estado y terapia nutricional en pacientes de neurocirugía electiva y urgencia
}

Márcia Maria Teixeira de Freitas'

ORCID: 0000-0003-3588-3969

Patrícia Stanich'

ORCID: 0000-0001-9064-0148

Solange Diccini'

ORCID: 0000-0001-8171-4467

' Universidade Federal de São Paulo. São Paulo, São Paulo, Brazil.

How to cite this article: Freitas MMT, Stanich P, Diccini S. Status and nutritional therapy in elective and emergency neurosurgery patients. Rev Bras Enferm [Internet]. 2019;72(1):73-80. DOI: http://dx.doi.org/10.1590/0034-7167-2017-0491

Corresponding Author:

Márcia Maria Teixeira de Freitas

E-mail:mmtfreitas@hotmail.com

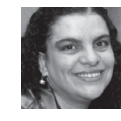

Submission: 07-06-2017

Approval: 07-06-2018

\section{ABSTRACT}

Objevect: To evaluate the Nutritional Status (NS) and follow the Enteral Nutritional Therapy (ENT) of patients in neurosurgical intervention. Method: Cohort study in emergency or elective surgery patients with exclusive ENT. Anthropometric measurements (Arm Circumference (AC and Triceps Skinfold (TSF)) were measured on the first, seventh and $14^{\text {th }}$ day. For the ENT monitoring, caloric/protein adequacy, fasting, inadvertent output of the enteral probe and residual gastric volume were used. Results: 80 patients, $78.7 \%$ in emergency surgery and $21.3 \%$ in elective surgery. There was a reduction in $A C$ and Body Mass Index (BMI) ( $p>0.01)$, especially for the emergency group. The caloric/protein adequacy was higher in the emergency group $(86.7 \%$ and $81.8 \%)$. Conclusion: The EN change was greater in the emergency group, even with better ENT adequacy. Changes in body composition are frequent in neurosurgical patients, regardless of the type of procedure.

Descriptors: Enteral Nutrition; Neurosurgery; Nutritional Evaluation; Malnutrition; Status.

\section{RESUMO}

Objetivo: Avaliar o Estado Nutricional (EN) e acompanhar a Terapia Nutricional Enteral (TNE) de pacientes em intervenção neurocirúrgica. Método: Estudo tipo coorte em pacientes de cirurgia de urgência ou eletiva, com TNE exclusiva. Foram aferidas medidas antropométricas (Circunferência do Braço (CB) e Dobra Cutânea Tricipital (DCT)) no primeiro, sétimo e $14^{\circ}$ dia. Para o monitoramento da TNE, utilizou-se: adequação calórico/proteica, jejum, saída inadvertida da sonda enteral e volume residual gástrico. Resultados: 80 pacientes, $78,7 \%$ em cirurgia de urgência e 21,3\% em eletiva. Houve redução da CB e do Índice de Massa Corporal (IMC) ( $p>0,01)$, em especial para o grupo de urgência. A adequação calórica/proteica foi superior no grupo de urgência (86,7\% e $81,8 \%)$. Conclusão: A alteração do EN foi maior no grupo de urgência mesmo com melhor adequação da TNE. A alteração da composição corporal é frequente em pacientes neurocirúrgicos, independentemente do tipo de procedimento.

Descritores: Nutrição Enteral; Neurocirurgia; Avaliação Nutricional; Desnutrição; Estado.

\section{RESUMEN}

Objetivo: Evaluar el Estado Nutricional (EN) y acompañar la Terapia Nutricional Enteral (TNE) de pacientes en intervención neuroquirúrgica. Método: Estudio tipo cohorte en pacientes de cirugía de urgencia o electiva, con TNE exclusiva. Se midieron medidas antropométricas (Circunferencia del Brazo (CB) y Pliegue Cutáneo Tricipital (PCT)) en el primer, séptimo y decimocuarto días. Para el monitoreo de la TNE: adecuación calórica/proteica, desayuno, salida inadvertida de la sonda enteral y volumen residual gástrico. Resultados: 80 pacientes, $78,7 \%$ en cirugía de urgencia y $21,3 \%$ en electiva. Hubo reducción de la CB y del Índice Masa Corporal (IMC) ( $p>0,01)$, en especial para el grupo de urgencia. La adecuación calórica/proteica fue superior en el grupo de urgencia (86,7\% y 81,8\%). Conclusión: La alteración del EN fue más alta en el grupo de urgencia mismo con mejor adecuación de la TNE. La alteración de la composición corporal es frecuente en pacientes neuroquirúrgicos independientemente del tipo de procedimiento.

Descriptores: Nutrición Enteral; Neurocirugía; Evaluación Nutricional; Desnutrición; Estado. 


\section{INTRODUCTION}

Early Enteral Nutritional Therapy (ENT) is essential for the treatment of neurological diseases and is associated with length of hospital stay ${ }^{(1)}$. According to guidelines for surgical patients, the recommendation is to achieve the energy needs until the seventh day to reduce mortality. In order to achieve the goal, it is recommended to initiate ENT between 24 and 48 hours postinjury for those with hemodynamic stability and Gastrointestinal Tract (GIT) functioning ${ }^{(1-3)}$.

After Traumatic Brain Injury (TBI), more than half of the patients present intolerance to ENT. There is a relationship between the intracranial pressure levels and the Glasgow Coma Scale (GCS) with the time of tolerance of ENT at stipulated concentration and volume $^{(1)}$. From the relationships established between the brain and the gastrointestinal system, intracranial pressure and gastric contractility are described. With increased intracranial pressure, there is a reduction of up to $80 \%$ in gastric contractility ${ }^{(1,4)}$. It is not uncommon for patients to present with gastrointestinal dysmotility, with the occurrence of diarrhea, constipation, nausea, vomiting and abdominal bloating ${ }^{(5)}$. ENT monitoring is of utmost importance for the effectiveness of treatment. Changing the Nutritional Status may be aggravated when ENT is not effective to meet nutritional needs. Severe patients undergo procedures that require fasting and interruption of ENT, situations that make it difficult to reach the programmed goals ${ }^{(6)}$. There is a shortage of information on the adequacy of calories and proteins, on the reasons for the cessation or delay of ENT in ICU patients and its relationship with changes in body composition ${ }^{(6)}$.

The pathophysiological mechanism of body alteration is multifactorial. The intensity of the metabolic changes in the acute phase depends on the severity of the brain injury, a situation aggravated by the coexistence of injuries from other systems ${ }^{(7)}$. The anthropometric evaluation aims to identify changes in body composition and measure the effects of nutritional therapy on the Nutritional Status of surgical patients ${ }^{(8)}$.

\section{OBJECTIVE}

This study aims to follow up ENT and evaluate the Nutritional Status of patients submitted to elective or emergency neurosurgery.

\section{METHOD}

\section{Ethical aspects}

The study was submitted and approved by the Ethics and Research Committee of the Universidade Federal de São Paulo (UNIFESP). Patients'representatives signed the Informed Consent Form (ICF) at the beginning of this study, accepting that patients were included.

\section{Design, place of study and period}

A quantitative, cohort and prospective study in a General and Neurological Intensive Care Unit (ICU) of a tertiary level hospital in São Paulo State (SP), in the city of São Paulo, during the years 2014 to 2016.

\section{Sample and criteria of exclusion and inclusion}

The sample size was determined considering the number of neurological surgeries performed in the year 2013, having as characteristics non-probabilistic and convenience. Inclusion criteria were patients older than 18 years, submitted to elective or emergency neurosurgery, with indication of exclusive ENT. The patients who received ENT prior to the surgical procedure and indication of oral diet were excluded.

\section{Study protocol}

The evaluated patients were divided according to the surgical classification in elective or emergency. For all patients, data were collected: age, gender, comorbidities, medical diagnosis, type of surgery (elective/emergency), Sequential Organ Failure Assessment (SOFA), Glasgow Coma Scale (GCS), anthropometric measurements, surgical procedure time and total volume of infused liquid ${ }^{(9)}$. Weight and height were considered for the classification of the Body Mass Index (BMI) according to age and anthropometric measures of Arm Circumference (AC) and Triceps Skinfold (TSF) ${ }^{(10)}$.

The follow-up time was 14 days, with anthropometric measurements on the first, seventh and $14^{\text {th }}$ days. The data collection was performed by the nutritionist, in the first 24 hours of the introduction of ENT with daily monitoring. For the estimation of nutritional needs, the values of 25 to 30 calories $/ \mathrm{kg} /$ day and 1.2 to $2.0 \mathrm{~g}$ protein/kg/day, also known as "Pocket Formula" and referenced in the literature ${ }^{(7)}$. For the monitoring of ENT, the adequacy of the caloric and protein supply, fasting, inadvertent exit of the enteral catheter and gastric residue were considered. The data collection was interrupted when the patient started oral diet, at the hospital discharge or death.

All patients received ENT by means of a catheter located in the gastric position. After radiological confirmation, the initiation of the diet's infusion in the open system was released, following validated procedures of production of enteral diets, according to current legislation ${ }^{(11)}$. The enteral formulas offered were polymeric and/or oligomeric, with fractionation of $3 / 3$ hours, with or without night break. The nutritionist was responsible for the evolution of the diets of the patients of this study. It started with normocaloric and normoproteic formula without addition of fibers, evolving to hypercaloric and hyperproteic formula with addition of fibers. In view of the frequency of the sedatives used based on lipid emulsion, nonprotein calories were also considered for the calculation of total calories. For the cases in which it was not possible to reach the protein target only with the prescribed enteral formula, the additional protein module was used.

\section{Analysis of results and statistics}

The data were annotated in a collection tool through the EPIINFO v.3.5.1 program ${ }^{(12)}$ and analyzed using Microsoft Excel software. The categorical variables were described in absolute value and relative frequency, while the continuous variables and submitted to the Kolmogorov-Smirnov Normality Test were described through measures of central tendency and dispersion. Initially, possible differences between basal and surgical characteristics were verified according 
to the two study groups. Pearson's Chi-square test or Fisher's exact test was used to analyze categorical variables and Student's T-Test or Mann-Whitney UTest for continuous variables. To verify the evolution of the anthropometric indicators, the non-parametric Friedman test was used stratified according to the type of surgery performed. For the comparison of ENT characteristics between groups, Student's T-Test or Mann-Whitney UTest were performed. Results were considered as statistically significant with probability of type I error lower than $5 \%$.

\section{RESULTS}

The initial casuistry was 83 patients, three patients were excluded due to lack of data. The sample consisted of 80 patients, 17 (21.3\%) of elective surgery and 63 (78.7\%) of the emergency surgery group. There was a predominance of males in both groups, with mean age of 55.4 years for the elective surgery group and 53.3 years for the emergency group. In general, the group submitted to emergency procedures had a higher frequency of comorbidities. No significant differences were observed in BMI, SOFA and baseline GCS between the groups. There was a greater frequency of cases of TBI and Stroke among patients submitted to emergency surgery, and in elective surgeries, neoplasias were predominant. The duration of surgery was higher among patients submitted to elective surgeries when compared to the emergency group (Table 1).

Table 2 shows the characteristics of ENT monitoring. Significant differences were observed regarding the time elapsed between surgery and the beginning of ENT. The percentage of caloric and protein adequacy indicators also did not show significant differences.

Nonprotein (parenteral) calories were present in $60 \%$ of the patients until the 3rd day of hospitalization with similar incidence between groups. From the 4th day, there was a higher frequency in the administration of calories among patients in the emergency surgery group. The contribution of calories to the daily Estimated Energy Requirement (EER) was decreasing in both groups during the first seven days. In general, there were no significant differences between the groups until the seventh day. As for the protein modulus, an increase in supply was observed during the first seven days. By the fourth day, the frequency of patients receiving protein modulus increased to approximately $72 \%$ in both groups, with superiority to the emergency group. From the fifth day, there is a reversal in the frequency of use of the protein module. Similar values were observed between groups on the fifth day, superiority among elective patients during the sixth day, and considerable superiority among patients in the elective group during the seventh day ( $90.9 \%$ vs $68.5 \%)$. The participation of the protein modulus on the Estimated Protein Need (EPN) during the first seven days presented a similarity between the surgical groups, showing no statistically significant difference during the first three days until the seventh day ( $p>0.05$ ) (Table 3 ).

Table 4 shows the frequency of GIT changes, occurring between the second and seventh days of ENT. In general, it was not possible to observe significant differences between the surgical groups, although the need for fasting among elective surgery patients during the second day occurred at a frequency almost twice as high, when compared to the need of patients in the emergency group ( $p=0.02$ ). The GIT changes were more frequent in the emergency group, but with no statistically significant difference.
Table 1 - Demographics and clinical characteristics of patients, according to type of elective and emergency surgery

\begin{tabular}{|c|c|c|c|}
\hline & \multicolumn{2}{|c|}{ Type of Surgery } & \multirow[b]{2}{*}{$\begin{array}{c}p \\
\text { value }\end{array}$} \\
\hline & $\begin{array}{l}\text { Elective } \\
(n=17)\end{array}$ & $\begin{array}{l}\text { Emergency } \\
\quad(n=63)\end{array}$ & \\
\hline \multicolumn{4}{|l|}{ Age } \\
\hline Mean \pm SD & $55.4 \pm 14.8$ & $53.3 \pm 17.9$ & 0.66 \\
\hline \multicolumn{4}{|l|}{ Gender } \\
\hline Male & $9(52.9 \%)$ & 35 (55.6\%) & \multirow{2}{*}{0.84} \\
\hline Female & $8(47.1 \%)$ & $28(44.4 \%)$ & \\
\hline \multicolumn{4}{|l|}{ Comorbidities } \\
\hline Diabetes Mellitus & $2(11.8 \%)$ & $10(15.9 \%)$ & 1.00 \\
\hline Hypertension & $7(41.2 \%)$ & $38(60.3 \%)$ & 0.17 \\
\hline Chronic Kidney Disease & $0(0 \%)$ & $1(1.6 \%)$ & -- \\
\hline \multicolumn{4}{|l|}{ Surgical indication } \\
\hline Trauma & $1(5.9 \%)$ & $27(42.9 \%)$ & $<0.01$ \\
\hline Stroke & $1(5.9 \%)$ & $15(23.8 \%)$ & 0.17 \\
\hline AMF/Aneurysm & $4(23.5 \%)$ & $16(25.4 \%)$ & 1.00 \\
\hline Neoplasm & $10(58.8 \%)$ & $2(3.2 \%)$ & $<0.01$ \\
\hline Others & 1 (5.9\%) & $3(4.7 \%)$ & --- \\
\hline \multicolumn{4}{|l|}{ SOFA * } \\
\hline Median & 10 & 9 & \multirow{2}{*}{0.65} \\
\hline Min - Max & $0-8$ & 019 & \\
\hline \multicolumn{4}{|l|}{$\mathrm{GCS}^{*}$} \\
\hline Median & 10 & 9 & \multirow[b]{2}{*}{0.14} \\
\hline Min - Max & $0-15$ & 0-19 & \\
\hline
\end{tabular}

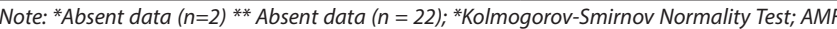
$=$ Arteriovenous Malformation; $B M I=$ Body Mass Index; $A C=$ Arm Circumference; TSF = Tricep Skinfold, SOFA = Sequential Organ Failure Assessment; GCS = Glasgow Coma Scale.

Table $\mathbf{2}$ - Relation between the medians, minimum and maximum of the time to the beginning, average percentage of caloric and protein adequacy of the Enteral Nutritional Therapy of the patients, according to the type of elective and emergency surgery

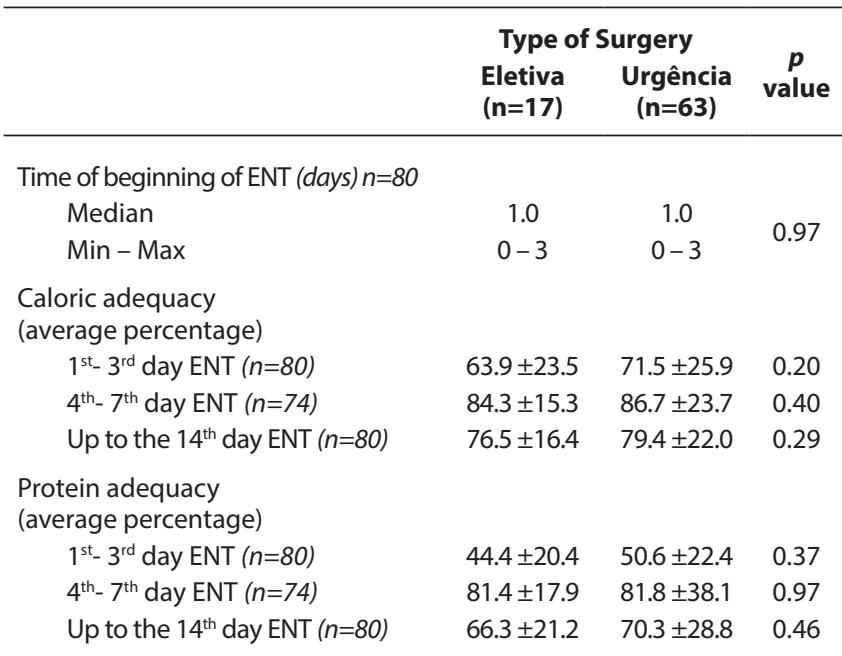

Note: ENT= Enteral Nutritional Therapy; *Student's T-Test or Mann-Whitney U Test.

In the assessment of Nutritional Status indicators, it was possible to observe a significant decline in $\mathrm{BMI}$ and $\mathrm{AC}$ values for patients in the emergency group. It can be observed that the patients presented reduction of $A C$, especially for patients in the emergency group $(p<0.01)$. Among the patients in the emergency group, median BMI decreased from $26.6 \mathrm{~kg} / \mathrm{m}^{2}$ to approximately $25.0 \mathrm{~kg} / \mathrm{m}^{2}$ at 
subsequent evaluations $(p<0.01)$. In relation to the fat mass compartment, demonstrated by TSF initially for the elective group, larger values are observed in relation to the emergency group (Table 5).

Table 3 - Relative participation of nonprotein calories and protein modulus isolated during the first week of ENT, according to the type of elective and emergency surgery

\begin{tabular}{|c|c|c|c|}
\hline & \multicolumn{2}{|c|}{ Type of Surgery } & \multirow[b]{2}{*}{$\begin{array}{c}p \\
\text { value }\end{array}$} \\
\hline & $\begin{array}{l}\text { Elective } \\
(n=17)\end{array}$ & $\begin{array}{l}\text { Emergency } \\
(n=63)\end{array}$ & \\
\hline \multicolumn{4}{|l|}{$\begin{array}{l}\text { Calorias Não Dietéticas (parenterais) } \\
\text { (percentual médio) }\end{array}$} \\
\hline $1^{\text {st }}-3^{\text {rd }}$ day ENT $(n=62)$ & $17.6 \pm 9.1$ & $17.6 \pm 9.6$ & 0.87 \\
\hline $4^{\text {th }}-7^{\text {th }}$ day ENT $(n=45)$ & $14.1 \pm 10.4$ & $12.1 \pm 9.3$ & 0.57 \\
\hline Up to the $7^{\text {th }}$ day ENT $(n=64)$ & $17.0 \pm 9.6$ & $15.2 \pm 8.1$ & 0.67 \\
\hline \multicolumn{4}{|l|}{$\begin{array}{l}\text { Proteína Isolada } \\
\text { (percentual médio) }\end{array}$} \\
\hline $1^{\text {st }}-3^{\text {rd }}$ day ENT $(n=12)$ & $26.0 \pm 6.1$ & $25.6 \pm 7.9$ & 0.95 \\
\hline $4^{\text {th }}-7^{\text {th }}$ day ENT $(n=34)$ & $24.2 \pm 12.3$ & $28.6 \pm 11.5$ & 0.40 \\
\hline Up to the $7^{\text {th }}$ day ENT $(n=36)$ & $31.1 \pm 16.8$ & $24.9 \pm 8.0$ & 0.34 \\
\hline
\end{tabular}

Table 4 - Association between the variables of Reflux or Gastrointestinal Residue, displacement of the probe and necessity of fasting in the first days of Enteral Nutritional Therapy, according to the type of elective and emergency surgery

\begin{tabular}{|c|c|c|c|}
\hline & \multicolumn{2}{|c|}{ Type of Surgery } & \multirow{2}{*}{$\begin{array}{c}p \\
\text { value }\end{array}$} \\
\hline & Elective & Emergency & \\
\hline \multicolumn{4}{|l|}{ Day $2(n=78)$} \\
\hline Reflux/GI Residue & $7(46.7 \%)$ & $22(34.9 \%)$ & 0.95 \\
\hline Probe displacement & $0(0 \%)$ & $3(4.7 \%)$ & \\
\hline Need for Fasting & $10(66.7 \%)$ & $23(34.9 \%)$ & 0.02 \\
\hline \multicolumn{4}{|l|}{ Day $3(n=76)$} \\
\hline Reflux/GI Residue & $6(40.0 \%)$ & $24(39.3 \%)$ & 0.96 \\
\hline Probe displacement & $2(13.3 \%)$ & $1(1.6 \%)$ & 0.09 \\
\hline Need for Fasting & $8(53.3 \%)$ & $25(41.0 \%)$ & 0.38 \\
\hline \multicolumn{4}{|l|}{ Day $4(n=73)$} \\
\hline Reflux/GI Residue & $7(50.0)$ & $24(40.7 \%)$ & 0.52 \\
\hline Probe displacement & $2(14.3 \%)$ & $0(0 \%)$ & \\
\hline Need for Fasting & $6(42.9 \%)$ & $24(40.7 \%)$ & 0.88 \\
\hline \multicolumn{4}{|l|}{ Day $5(n=69)$} \\
\hline Reflux/GI Residue & $4(30.8 \%)$ & 27 (48.2\%) & 0.25 \\
\hline Probe displacement & $1(7.7 \%)$ & 4 (7.1\%) & 1.00 \\
\hline Need for Fasting & $2(15.4 \%)$ & $18(32.1 \%)$ & 0.23 \\
\hline \multicolumn{4}{|l|}{ Day $6(n=68)$} \\
\hline Reflux/GI Residue & $3(25.0 \%)$ & $21(37.5 \%)$ & 0.41 \\
\hline Probe displacement & $0(0 \%)$ & $6(10.7 \%)$ & \\
\hline Need for Fasting & $2(16.7 \%)$ & $18(32.1 \%)$ & 0.28 \\
\hline \multicolumn{4}{|l|}{ Day $7(n=64)$} \\
\hline Reflux/GI Residue & $3(27.3 \%)$ & $20(38.5 \%)$ & 0.48 \\
\hline Probe displacement & $2(18.2 \%)$ & $6(11.3 \%)$ & 0.53 \\
\hline Need for Fasting & $4(36.4 \%)$ & $18(34.0 \%)$ & 0.87 \\
\hline
\end{tabular}

Note: GI = Gastrointestinal; *Kolmogorov-Smirnov Normality Test.

It was possible to observe an equal frequency of hospital discharge and death in patients in the elective group (29.4\%). For patients in the emergency group, $20.6 \%$ died and $15.9 \%$ were discharged from hospital, however, with no significant difference $(p<0.29, p<0.51)$. When comparing the groups, patients submitted to elective surgery had a higher death rate, suggesting that patients in the emergency surgery group remained hospitalized for a period of more than 14 days.

Table 5 - Association between variables of the median, minimum and maximum values of the Body Mass Index, Arm Circumference and Triceps Skinfold at the initial time, seven days and 14 days of Enteral Nutritional Therapy, according to the type of elective and emergency surgery

\begin{tabular}{lcccc}
\hline & Inicial & $\mathbf{7}$ dias & $\mathbf{1 4}$ dias & $\begin{array}{c}\boldsymbol{p} \\
\text { value }\end{array}$ \\
\hline Elective & $\mathrm{n}=17$ & $\mathrm{n}=14$ & $\mathrm{n}=8$ & \\
$\mathrm{BMI}\left(\mathrm{kg} / \mathrm{m}^{2}\right)$ & $27.1(19.0 ; 38.2)$ & $28.5(17.0 ; 38.4)$ & $28.3(17.3 ; 38.7)$ & 0.79 \\
$\mathrm{AC}(\mathrm{cm})$ & $32.0(25.3 ; 39.0)$ & $31.9(23.7 ; 39.2)$ & $30.6(24.0 ; 39.5)$ & 0.74 \\
TSF $(\mathrm{mm})$ & $21.0(8.0 ; 45.0)$ & $19.8(7.5 ; 43.2)$ & $22.5(11.5 ; 42.8)$ & 0.67 \\
Urgência & $\mathrm{n}=63$ & $\mathrm{n}=52$ & $\mathrm{n}=33$ & \\
BMI $\left(\mathrm{kg} / \mathrm{m}^{2}\right)$ & $26.6(18.0 ; 41.8)$ & $24.9(13.2 ; 39.0)$ & $25.0(15.2 ; 39.5)$ & $<\mathbf{0 . 0 1}$ \\
AC $(\mathrm{cm})$ & $30.3(24.0 ; 43.0)$ & $29.5(19.3 ; 42.0)$ & $28.5(21.4 ; 42.4)$ & $<\mathbf{0 . 0 1}$ \\
TSF $(\mathrm{mm})$ & $16.7(1.7 ; 44.0)$ & $15.6(1.5 ; 39.0)$ & $16.0(1.8 ; 32.0)$ & 0.14
\end{tabular}

Note: *Friedman test (non-parametric ANOVA for repeated measures); BMI = Body Mass Index $A C=$ Arm Circumference; $T S F=$ Triceps Skinfold.

\section{DISCUSSION}

The sample of this study presented demographic and clinical characteristics comparable to another study performed in severe patients ${ }^{(9)}$ in relation to the age distribution, gender, comorbidities and their respective surgical indications. There was a predominance in the adult male gender, data consistent with the literature, justified by the higher incidence of trauma $a^{(9,13-14)}$. The presence of comorbidities in ICU patients is common. In this study, Hypertension was found in $57 \%$ and Diabetes Mellitus (DM) in 15\% of the patients studied, with a higher incidence in patients in the emergency group ${ }^{(15)}$.

The moderate TBI was the main diagnosis found in the emergency surgery group, followed by Stroke. Surgical treatment can be performed depending on the expansion and/or location of the hematoma ${ }^{(16)}$. The profile of chronic diseases of the Brazilian population, the aging population and the increase in the incidence of cancer may justify the occurrence of brain neoplasm as the main cause found in elective surgeries. Although the literature describes different degrees of severity in neurosurgical patients in the ICU, the present study did not observe significant differences in the score of the SOFA and GCS scales, data consistent with the Jain study in $2007^{(17)}$.

ENT was started in the first 24 hours (24-72h) for all patients, according to the international guidelines on intensive care ${ }^{(7)}$. Consistent with these results, in a multicenter study, mean values for the ENT onset of 42.1 hours ${ }^{(18)}$. O'Meara et al., In 2008, observed that the mean time to onset of ENT was 18.2 hours $^{(19)}$. ENT, when started early, is associated with a lower occurrence of clinical complications, decreased mortality, and length of ICU stay ${ }^{(8,20)}$. The programmed caloric goal was reached in 96 hours, considering the contribution of non-dietary (parenteral) calories. The result corroborates the Brazilian study conducted by Martins et al. ${ }^{(21)}$, where $80 \%$ of the goal was reached on the fourth day of ENT. Similarly, the authors included patients in the ICU and infirmary who received enteral nutrition in the open system, whose process 
requires manipulation of the enteral formula, with packaging for administration in intermittent periods ${ }^{(21)}$. The energy deficit accumulated in the first week in the ICU is described as a strong predictor of clinical outcomes, and the delay to the start of ENT may expose the patients to the energy deficit, which probably will not be compensated during hospitalization ${ }^{(22)}$. Tsai and colleagues evaluated associations between calories and protein consumed in the first week of ICU admission and outcomes. They found that patients who received less than $60 \%$ of the prescribed calories had a higher mortality risk ${ }^{(23)}$. On the other hand, Arabi and colleagues evaluated the effect of permissive sub-offer (60 to $70 \%$ ) versus adequate supply (90 to 100\%) in clinical outcomes, the group that received an average of $59 \%$ hospital mortality rates when compared with the rates of the group receiving $71.4 \%{ }^{(24)}$. Protein intake also deserves attention, although reaching the hyperproteic prescription with available enteral formulas is often a limiting factor. Protein adequacy was observed from the fourth day of ENT. An alternative found was the supplementation with isolated protein modulus diluted to $15 \%$, by volume of 100 to $500 \mathrm{ml} /$ day, according to the individual needs, which allowed the addition of up to $60 \mathrm{~g}$ of proteins per day. The use of enteral formula with 1.2 to 1.5 calories $/ \mathrm{mL}$ and protein values between 44 and 65 grams/liter, respectively, did not allow the caloric and protein adequacy, without the use of modular protein, in ICU patients ${ }^{(25-26)}$.

It was observed that the caloric and protein adequacy in the first three days of ENT showed superiority in the emergency group. The adequacy indicators, when calculated from the fourth to the seventh day, in addition to the total adequacy indicator (up to the $14^{\text {th }}$ day) showed very close values between the groups. Nonprotein calories had a caloric adequacy of $60 \%$, with higher percentages for patients in the emergency group. This was due to the use of larger doses of sedatives to control intracranial pressure. Although sedation remained for both groups from the fourth day onwards, there was a decline in this treatment. The use of lipid emulsion-based sedative (Propofol) is a reality in the ICUs and has contributed to the early caloric adequacy in the validity of nutritional therapy. When administered in doses higher than $20 \mathrm{~mL} /$ hour, in combination with any type of nutritional therapy, it can lead to overnutrition, a situation associated with hyperglycemia, hepatic steatosis and hypertriglyceridemia ${ }^{(27)}$. The guidelines recommend that the nutritional intake administered be as close to the patient's needs as possible, to avoid nutritional deficiencies, to attenuate lean mass loss, to avoid complications, and to improve clinical outcomes ${ }^{(28)}$.

In this study, the factors considered for the non-supply of ENT were: the need for fasting for any type of procedure, the presence of gastric residue higher than $200 \mathrm{~mL} /$ hour and/or reflux and the inadvertent exit of the enteral tube only in the first seven days from ENT. The analysis was thus driven by the fact that, after this period, the events were sporadic and some patients were withdrawn from the study, following the criteria of censorship initially proposed. It can be observed that the events were more frequent in the elective group, especially the need for fasting. Elevated gastric residue in the first days of ENT may be related to an increase in intracranial pressure in the emergency group and also to the positioning of the probe at the gastric level and the infusion ENT method ${ }^{(19)}$. For the inadvertent output of the probe, the percentage was low, demonstrating the commitment of all the team with the effectiveness of the therapy. In another study, the gastric residue was also presented as one of the main occurrences, although in a smaller volume ${ }^{(19)}$. One possible explanation for this lower incidence would be the positioning of the post-pyloric probe, which seems to provide better tolerance to the diet. Severe patients may present with gastroparesis and increased gastric residue, with gastric stasis being one of the main measurable causes limiting ENT ${ }^{(28)}$. Changes in GIT were more frequent until the seventh day of follow-up, a fact that led to the non-presentation of the variable until the $14^{\text {th }}$ day. For all patients in the emergency surgery group, the outcomes observed were: longer hospitalization, precocity in the introduction of oral diet and lower percentage of death. The mechanism of rehabilitation of adult patients with acute neurological disease seems better than in patients with acute or chronic acute illnesses ${ }^{(29)}$.

The BMI, an anthropometric indicator used as an evaluation tool, can be considered a predictor of mortality, when values lower than $18.5 \mathrm{~kg} / \mathrm{m}^{2}$, while high values of this indicator seem to be associated with favorable results, independent of the conventional predictors. However, it is important to consider the limitations of the method, since severe patients have body weight modified by changes in intra- and extracellular compartments ${ }^{(30)}$. The initial Nutritional Status, in both groups, was overweight. Although overweight in the adult population is related to risk factors for cardiovascular disease, in neurological patients it seems to have a protective factor. Excess body fat protects the body against loss of muscle mass, a common situation in neurological patients and, more recently, also described for severe patients ${ }^{(31)}$. Due to the body changes presented, even for overweight patients, there was reduction of $\mathrm{BMI}$ in the emergency surgery group. In the severe patient, the evaluation of Nutritional Status is a great challenge, since the evaluated parameters can be influenced purely by the inflammation, and did not represent the nutritional questions, often reflecting the severity of the disease with its systemic repercussion. Drug therapy also interferes with its values, such as the need for volume expansion during hemodynamic balance ${ }^{(32)}$.

Changes in body composition in ICU patients are directly related to the fluid supply and intensity of the injury, with the lean mass compartment more affected by proteolysis and decreased protein turnover. The reserves of body fat are consumed for the generation of energy by changing the body compartments. Objective nutritional assessment may not reflect the actual situation of reservations in a short period of time ${ }^{(32)}$. The main alterations in body composition, due to anthropometric measurements, were more frequent in patients in the emergency group, where the $\mathrm{TBI}$ was the diagnosis of higher prevalence.

The neuroendocrine response to acute injury occurs through an intense mobilization of nutritional stocks, due to the process of protein synthesis. Precisely at this point, ENT becomes essential to provide substrates. Both overnutrition and undernutrition carry with them the worsening of metabolic disorders, compromising the evolution of the severe patient, justifying the attention for the progression of $\mathrm{ENT}^{(33-34)}$. Severe patients receive nutritional support lower than their needs, compromising the Nutritional Status, due to factors intrinsic to the acute phase of the disease and also of iatrogenic factors, which act as a barrier to the administration 
of $\mathrm{ENT}^{(34)}$. Although the BMI does not demonstrate the actual commitment of Nutritional Status in severe patients, and the use of the equations does not estimate the actual nutritional needs, these are mechanisms widely used in clinical practice. This study highlights the importance of monitoring and follow-up of ENT ${ }^{(35)}$.

\section{Study limitations}

In the present research, some limitations were observed. Firstly, because it was developed in a single school hospital, and because of the fact that, during the study, there was a reduction in the performance of elective surgeries, determining the inequality among the participants. In view of the variety of factors that interfere in the monitoring of ENT, some measures could better ensure therapy in severe patients such as: institutional protocols, specific enteral formula and multidisciplinary team performance.

\section{Contributions to the sector of Health}

Although it is already a reality in most health institutions, ENT should be monitored routinely, since it can be adopted as an indicator of the quality of nutritional assistance provided by the nutritionist, along with the multidisciplinary team. This proposal assumes an important role when considering the difficulties to obtain viable nutritional parameters for patients in neurosurgery.

\section{CONCLUSION}

Regarding Nutritional Status, it was observed that patients in the emergency surgery group had a worse result regarding the $\mathrm{BMI}$ and $\mathrm{AC}$ values when compared to the elective surgery group. Regarding body fat mass, patients in the elective surgery group presented higher values than those in the emergency group. The nutritional monitoring of ENT in neurosurgical patients may allow the caloric/protein supply to be more quickly reached; in relation to the parameters evaluated, fasting was the most predominant variable for the interruption of ENT. The indication and the caloric/protein adequacy were completed by the fourth day for both groups. The indication of ENT was early and its follow-up proved to be effective, since with adequate ENT in terms of caloric and protein supply, it can be provided that the individualized nutritional need is more quickly achieved.

\section{REFERENCES}

1. Riboldi BP, Contini B, Santos FT, Silva LS, Oliveira VR, Cunha FM, Santis-isolan PMB, Osolan GR. [Nutrition and neurosurgery: a review]. J Bras Neurocir [Internet]. 2011 [cited 2016 Oct 29];22(2):38-43. Available from: http://www.ceanne.com.br/revista/wp-content/uploads/2014/11/ Nutricao-e-neurolog.pdf Portuguese.

2. Sociedade Brasileira de Nutrição Parental e Enteral, Associação Brasileira de Nutrologia. Terapia Nutricional no Paciente Grave [Internet]. São Paulo: AMB, Conselho Federal de Medicina; 2011 [cited 2016 Oct 01]. 16 p. Available from: https://diretrizes.amb.org.br/_BibliotecaAntiga/ terapia_nutricional_no_paciente_grave.pdf

3. Chiang Y-H, Chao D-P, Chu S-F, Lin H-W, Huang S-Y, Yeh Y-S et al. Early enteral nutrition and clinical outcomes of severe traumatic brain injury patients in acute stage: a multi-center cohort study. J Neurotrama [Internet]. 2012 [cited 2016 Oct 01];29(1):75-80. Available from: doi: https://doi.org/10.1089/neu.2011.1801

4. Abreu JP, Von Bahten LC, Tannous L. O valor da contagem de SOFA em predizer o prognóstico e a mortalidade de pacientes cirúrgicos da UTI do Hospital Universitário Cajuru [Internet]. In: XVII Seminário de Iniciação Científica, V PIBIC Jr, XII Mostra de Pesquisa, II SPPGEM. Paraná: PUCPR; 27 e 28 Out 2009. [cited 2016 Oct 29]. Available from: http://www2.pucpr.br/reol/index.php/semic17?dd99=view\&dd1=3032

5. Bretón I. Nutritional support in neurological diseases Topic 25: Module 25.1: Nutritional and metabolic consequences of neurological diseases [Internet]. [place unknown]: LLL Programme in Clinical Nutrition and Metabolism. 2016 [cited 2017 Jan 10]. 12 p. Available from: http://IIInutrition.com/mod_III/TOPIC25/m251.pdf

6. Arabi YM, Casaer MP, Chapman M, Heyland DK, Ichai C, Marik PE, Martindale RG, McClave SA, Preiser JC, Reignier J, Rice TW, Van den Berghe G, van Zanten AR, Weijs PJ. The intensive care medicine research agenda in nutrition and metabolism. Intensive Care Med. 2017;43(9):12391256. doi 10.1007/s00134-017-4711-6

7. McClave SA, Taylor BE, Martindale RG, Warren MM, Johnson DR, Braunschweig C, McCarthy MS, Davanos E, Rice TW, Cresci GA, Gervasio JM, Sacks GS, Roberts PR, Compher C; Society of Critical Care Medicine; American Society for Parenteral and Enteral Nutrition. Guidelines for the Provision and Assessment of Nutrition Support Therapy in the Adult Critically III Patient: Society of Critical Care Medicine (SCCM) and American Society for Parenteral and Enteral Nutrition (ASPEN). JPEN J Parenter Enteral Nutr. 2016;40(2):159-211. doi: $10.1177 / 0148607115621863$

8. Weijs PJ, Looijaard WG, Dekker IM, Stapel SN, Girbes AR, Oudemans-van Straaten HM, et al. Low skeletal muscle area is a risk factor for mortality in mechanically ventilated critically ill patients. Crit Care [Internet]. 2014 [cited 2016 Jun 20];18(1):R12. Available from: doi:10.1186/ cc13189

9. Tan M, Zhu J-C, Yin H-H. Enteral nutrition in patients with severe traumatic brain injury: reasons for intolerance and medical management. Br J Neurosurg [Internet]. 2011 [cited 2016 Oct 01];25(1):2-8. Available from: https://doi.org/10.3109/02688697.2010.522745

10. Lee RD, Nieman DC. Nutritional assessment of the Hospitalized Patient. In: Nutritional assessment. 2a ed. St Louis, Mo: Mosby-Year Book [Internet]. 1996 [cited 2016 Oct 20]; p. 289-329. Available from: http://agris.fao.org/agris-search/search.do?recordID=US19960130785

11. Ministério da Saúde (BR), Secretaria da Vigilância Sanitária (ANVISA). Resolucao RDC ANVISA 63-2000. Regulamento Técnico para Terapia de 
Nutrição Enteral [Internet]. Diário Óficial da União: República Federativa do Brasil. 2000 [cited 2016 May 20]. Jul 7, Seção 1:p. 89. Available from: http://www.cofen.gov.br/wp-content/uploads/2017/05/RDC-63_2000.pdf

12. Centers for Disease Control and Prevention (CDC). Epi Info ${ }^{\mathrm{TM}}$ for Windows [Software]. Atlanta (GA): CDC; 2008 [cited 2016 May 20 ]. Available from: https://wwwn.cdc.gov/epiinfo/html/prevVersion.htm

13. Tavares $C B$, Sousa EB, Borges IBC, Braga F das CSA, others. [Patients with brain injury surgically treated in neurosurgery service at hospital de base do Distrito Federal (Brasilia, Brazil)]. Arq Bras Neurocir [Internet]. 2014 [cited 2016 Oct 29];33(3):225-32 Available from: doi:10.1055/s-0038-1626218 Portuguese.

14. Kim H, Shin JA, Shin JY, Cho OM. Adequacy of nutritional support and reasons for underfeeding in neurosurgical intensive care unit patients. Asian Nurs Res [Internet]. 2010 [cited 2016 Oct 02];4(2):102-110. Available from: http://www.asian-nursingresearch.com/article/ S1976-1317(10)60010-2/pdf

15. de Paula Silva MP, Carvalho NZ, Pires JO, Paula PH, Gomes GLO, Costa CKF, et al. [Avoidable hospitalization causes in intensive care units]. Iniciaç Cient Cesumar [Internet]. 2013 [cited 2016 Nov 01];15(2):147-55. Available from: http://periodicos.unicesumar.edu.br/index.php/ iccesumar/article/view/3189 Portuguese.

16. Figueiredo MM, Bichuetti DB, Gois AFT. [Evidence on diagnosis and treatment of stroke in the emergency department]. Diagn Tratamento [Internet]. 2012 [cited 2016 Oct 29]; 17(4):167-72. Available from: http://files.bvs.br/upload/S/1413-9979/2012/v17n4/a3328.pdf Portuguese.

17. Jain G, Mukerji G, Dixit A, Manshani N, Yadav YR. The impact of nutritional status on the outcome of Indian patients undergoing neurosurgical shunt surgery. Br J Nutr [Internet]. 2007 [cited 2016 Oct 02];98(5):944-949. Available from: doi: doi:10.1017/ S0007114507749218

18. Heyland DK, Dhaliwal R, Drover JW, Gramlich L, Dodek P. Canadian clinical practice guidelines for nutrition support in mechanically ventilated, critically ill adult patients. JPEN J Parenter Enteral Nutr [Internet]. 2003 [cited 2016 Nov 01];27(5):355-373. Available from: https:// doi.org/10.1177/0148607103027005355

19. O'Meara D, Mireles-Cabodevila E, Frame F, Hummell AC, Hammel J, Dweik RA, et al. Evaluation of delivery of enteral nutrition in critically ill patients receiving mechanical ventilation. Am J Crit Care [Internet]. 2008 [cited 2016 Nov 01];17(1):53-61. Available from: http://ajcc. aacnjournals.org/content/17/1/53.short

20. Santos FA, Viana KDAL. [Assessment of nutritional status and therapeutic diet of patients in an intensive care unit]. Rev Pesq Saúde [Internet]. 2016 [cited 2016 Nov 01];17(1):42-46. Available from: http://www.periodicoseletronicos.ufma.br/index.php/revistahuufma/ article/view/5502 Portuguese.

21. Martins JR, Shiroma GM, Horie LM, Logullo L, Silva ML, Waitzberg DL. Factors leading to discrepancies between prescription and intake of enteral nutrition therapy in hospitalized patients. Nutrition [Internet]. 2012 [cited 2016 Nov 01];28(9):864-867. Available from: https://doi. org/10.1016/j.nut.2011.07.025

22. Ochoa Gautier JB, Martindale RG, Rugeles SJ, Hurt RT, Taylor B, Heyland DK, McClave SA. How Much and What Type of Protein Should a Critically III Patient Receive? Nutr Clin Pract [Internet]. 2017 [cited 2017 May 20];32(1S):6S-14S. Available from: https://doi. org/10.1177/0884533617693609

23. Tsai J-R, Chang W-T, Sheu C-C, Wu Y-J, Sheu Y-H, Liu P-L, et al. Inadequate energy delivery during early critical illness correlates with increased risk of mortality in patients who survive at least seven days: a retrospective study. Clin Nutr [Internet]. 2011 [cited 2016 Nov 01]; 30(2): 209-214. Available from: https://doi.org/10.1016/j.clnu.2010.09.003

24. Arabi YM, Tamim HM, Dhar GS, Al-Dawood A, Al-Sultan M, Sakkijha MH, et al. Permissive underfeeding and intensive insulin therapy in critically ill patients: a randomized controlled trial. Am J Clin Nutr [Internet]. 2011 [cited 2016 Nov 01];93(3):569-577. Available from: https:// doi.org/10.3945/ajen.110.005074

25. da Cunha HFR, Eiras E, da Rocha M, Hissa M. Protein requirements, morbidity and mortality in critically ill patients: fundamentals and applications. Rev Bras Ter Intensiva [Internet]. 2013 [cited 2016 Nov 01];25(1):49-55. Available from: http://dx.doi.org/10.1590/ S0103-507X2013000100010

26. Rugeles SJ, Ochoa Gautier JB, Dickerson RN, Coss-Bu JA, Wernerman J, Paddon-Jones D. How Many Nonprotein Calories Does a Critically III Patient Require? A Case for Hypocaloric Nutrition in the Critically III Patient. Nutr Clin Pract [Internet]. 2017 [cited 2017 May 20]; 32(1S):72S76S. Available from: https://doi.org/10.1177/0884533617693608

27. Barbosa FT. Propofol infusion syndrome. Rev Bras Anestesiol [Internet]. 2007 [cited 2016 Nov 01];57(5):539-542. Available from: http://www. scielo.br/pdf/rba/v57n5/en_09.pdf

28. Heyland DK, Weijs PJ, Coss-Bu JA, Taylor B, Kristof AS, O'Keefe GE, Martindale RG. Protein delivery in the Intensive Care Unit: Optimal or Suboptimal? Nutr Clin Pract [Internet]. 2017 [cited 2017 May 20];32(1S):58S-71S. Available from: https://doi.org/10.1177/0884533617691245

29. de Nadai Dias LI, Novaes Paraizo MF, dos Santos Stefanutto A, Dantas de Sousa R, Firmino Pinto MR. Revisão sobre a reorganização funcional após lesão cerebral. Ens Cien: Cien Agrar Biol Saúde. [Internet]. 2011 [cited 2016 Nov 01];15(6):207-218. Available from: http://www.redalyc. org/html/260/26024221015/

30. Fontoura CSM, Cruz DO, Londero LG, Vieira RM. [Nutritional assessment of the critical ill patient]. Rev Bras Ter Intensiva [Internet]. 2006 [cited 2016 Oct 29];18(3):298-306. Available from: http://dx.doi.org/10.1590/S0103-507X2006000300013 Portuguese.

31. Hung JW, Chou CX, Hsieh YW, Wu WC, Yu MY, Chen PC, et al. Randomized comparison trial of balance training by using exergaming and conventional weight-shift therapy in patients with chronic stroke. Arch Phys Med Rehabil [Internet]. 2014 [cited 2016 Nov 01]; 
95(9):1629-1637. Available from: https://doi.org/10.1016/j.apmr.2014.04.029

32. Mogensen KM, Horkan CM, Purtle SW, Moromizato T, Rawn JD, Robinson MK, Christopher KB. Malnutrition, Critical Illness Survivors, and Postdischarge Outcomes: A Cohort Study. JPEN J Parenter Enteral Nutr [Internet]. (2017) [cited 2017 Jun 20]; 1:148607117709766. Available from: https://doi.org/10.1177/0148607117709766

33. Petros S, Horbach M, Seidel F, Weidhase L. Hypocaloric vs normocaloric nutrition in critically ill patients: a prospective randomized pilot trial. JPEN J Parenter Enteral Nutr [Internet]. 2016 [cited 2017 Jan 20];40(2):242-249.Available from: https://doi.org/10.1177/0148607114528980

34. Rugeles S, Villarraga-Angulo LG, Ariza-Gutiérrez A, Chaverra-Kornerup S, Lasalvia P, Rosselli D. High-protein hypocaloric vs normocaloric enteral nutrition in critically ill patients: a randomized clinical trial. J Crit Care [Internet]. 2016 [cited 2017 Jan 20];35:110-114. Available from: https://doi.org/10.1016/j.jcrc.2016.05.004

35. Ribeiro LMK, Oliveira Filho RS, Caruso L, Lima PA, Damasceno NRT, Soriano FG. Adequacy of energy and protein balance of enteral nutrition in intensive care: what are the limiting factors? Rev Bras Ter Intensiva [Internet]. 2014 [cited 2016 Nov 01];26(2):155-162. Available from: http://dx.doi.org/10.5935/0103-507X.20140023 